\title{
Final Monitoring Plan for the Utica Aquifer- North Lake Basin Restoration Project at Utica, Nebraska
}

\section{Environmental \\ Research Division \\ Argonne National Laboratory}

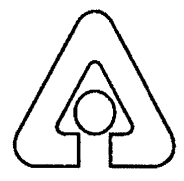

Operated by The University of Chicago,

under Contract W-31-109-Eng-38, for the

United States Department of Energy 


\section{Final Monitoring Plan for the Utica Aquifer- North Lake Basin Restoration Project at Utica, Nebraska}

Applied Geosciences and Environmental Management Section, Environmental Research Division,

Argonne National Laboratory, 9700 South Cass Avenue, Argonne, Illinois 60439-4843

November 2004

Work sponsored by Commodity Credit Corporation, United States Department of Agriculture 


\section{Contents}

Notation

1 Introduction

1.1 Background

1.2 Overview of the Aquifer and Wetlands Restoration Facilities.....

1.3 Regulatory Status of the Utica Program

2 Sampling and Monitoring Points.

2.1 Sampling Points for the Groundwater Extraction Wells and the Treatment Systems.

2.2 Existing Sampling and Monitoring Points for the Groundwater Plume

2.3 Recommendations for Additional Permanent Monitoring Wells

3 Monitoring Programs

3.1 Initial (Confirmation) Sampling and Monitoring.

3.2 Long-Term Sampling and Monitoring

3.3 Procedures for Sampling and Analyses

4 References

\section{Figures}

1.1 Locations of the primary groundwater extraction and treatment facilities at Utica, Nebraska

2.1 Locations of wells, steel drive-point piezometers, and cone penetrometer piezometers available for groundwater level monitoring and sampling as of June 10, 2004, relative to the carbon tetrachloride plume as mapped in February 2003

2.2 Suggested locations for new monitoring wells, relative to the groundwater extraction wells and the carbon tetrachloride plume as mapped in February 2003 ........

\section{Tables}

1.1 Agencies participating with the CCC/USDA in the Utica-North Lake Basin pilot program

2.1 Construction information for existing potential sampling and monitoring points at Utica.

3.1 Monitoring plan for the Utica spray irrigation treatment system 


\section{Notation}

$\begin{array}{ll}\text { BGL } & \text { below ground level } \\ \text { CCC } & \text { Commodity Credit Corporation } \\ \text { CPT } & \text { cone penetrometer } \\ \text { EPA } & \text { U.S. Environmental Protection Agency } \\ \mathrm{ft} & \text { foot (feet) } \\ \text { gpm } & \text { gallon(s) per minute } \\ \text { GWEX } & \text { groundwater extraction } \\ \text { hr } & \text { hour(s) } \\ \text { ID } & \text { inner diameter } \\ \text { in. } & \text { inch(es) } \\ \text { MW } & \text { monitoring well } \\ \text { NDEQ } & \text { Nebraska Department of Environmental Quality } \\ \text { NGPC } & \text { Nebraska Game and Parks Commission } \\ \text { NPDES } & \text { National Pollutant Discharge Elimination System } \\ \text { RAMS } & \text { Reinke Automated Management System } \\ \text { SDP } & \text { steel drive-point (piezometer) } \\ \text { USDA } & \text { U.S. Department of Agriculture } \\ \text { VOC } & \text { volatile organic compound }\end{array}$




\section{Final Monitoring Plan for the Utica Aquifer-North Lake Basin Restoration Project at Utica, Nebraska}

\section{Introduction}

\subsection{Background}

On March 9, 2001, representatives of the Commodity Credit Corporation of the U.S. Department of Agriculture (CCC/USDA) and Argonne National Laboratory met with representatives from a number of federal and Nebraska state agencies (the wetlands agencies; see Table 1.1) to discuss the CCC/USDA's proposed aquifer remediation and wetlands restoration project at Utica, Nebraska. As part of those discussions, Argonne outlined preliminary recommendations for a long-term monitoring program to verify and document (1) the performance of the spray irrigation treatment process for the removal of carbon tetrachloride from extracted groundwater, (2) the geochemical quality of the extracted and treated groundwater delivered to the wetlands, and (3) the hydrogeologic and inorganic geochemical impacts of the groundwater delivery. General activities recommended included the following:

- Periodic sampling and analysis for volatile organic compounds (VOCs) in groundwater extracted at each pumping well and in water discharged from the spray irrigation treatment units.

- Periodic sampling of groundwater from each pumping well and directly from the sprinkler discharge, for analysis for selected inorganic water quality parameters.

The CCC/USDA and Argonne also requested at the March 2001 meeting that the wetlands agencies accept responsibility for developing the ecological and biological monitoring programs needed to meet environmental requirements for the wetlands restoration program.

The preliminary recommendations for monitoring outlined above were generally accepted by the wetlands agencies. Since the March 2001, meeting, however, no further discussions have taken place (to Argonne's knowledge) regarding potential monitoring at this site. As the design of the Utica project has evolved, more detailed technical information has become available regarding the specific restoration activities to be performed in association with 
the aquifer and the wetlands basin. The scope of the aquifer restoration has also expanded to include the addition of a fourth groundwater extraction (GWEX) well and a dedicated treatment system (now required for containment and recovery of the carbon tetrachloride plume) that will be operated independently of the seasonal spray irrigation system.

This document presents updated recommendations for initial groundwater sampling, for subsequent long-term groundwater monitoring, and for monitoring of the treatment systems that will be required to comply with the National Pollutant Discharge Elimination System (NPDES) permit requested from the Nebraska Department of Environmental Quality (NDEQ) for the Utica site. Argonne again suggests that the wetlands agencies accept responsibility for planning and implementing any monitoring that might be required to evaluate the progress of the wetlands ecosystem restoration.

\subsection{Overview of the Aquifer and Wetlands Restoration Facilities}

The primary features of the extraction and treatment systems are illustrated in Figure 1.1. Four GWEX wells lie along the approximate axis of the groundwater carbon tetrachloride plume. Wells GWEX1, GWEX2, and GWEX3 are located north of the railroad tracks and are linked by a common pipeline to convey contaminated groundwater to the North Lake Basin. Pumping of these wells will be seasonal, at a target combined flow rate of approximately $375 \mathrm{gpm}$. These wells will be operated simultaneously from a central control building just west of GWEX2.

At the wetlands, groundwater can be directed (via a manually operated valve) to either of two spray irrigation units designed to volatilize carbon tetrachloride from the groundwater as it is discharged. Each unit consists of three irrigation spans. Only one spray irrigation unit can be operated at a time. A computerized RAMS (Reinke Automated Management System) panel at each spray site will monitor the functions of the spray irrigation unit to which it is dedicated. Each RAMS panel is linked to a base station computer at the control building. The RAMS panels also control and monitor the extraction wells and provide fail-safe measures in the event of system malfunctions. The RAMS panels and the base computer are also linked to a recording weather station at the wetlands. Modem communications with the RAMS panels via the base station computer permit remote determination of the systems' status and selection of operating parameters. 
The spray irrigation units have been sited to discharge treated groundwater to either of two subbasins within the wetlands. The subbasins are separated by the east-west county road that crosses the wetland area toward its northern end. A water control structure installed beneath the road can be used to control the water levels and the movement of water between the subbasins at the discretion of the wetlands agencies.

The fourth extraction well (GWEX4), located near the toe of the groundwater plume, is designed to pump continuously at an approximate rate of $70 \mathrm{gpm}$. A low-profile tray-type air stripper will treat the well effluent before it is discharged to a nearby open ditch along the adjacent north-south county road. (This well could not be linked to the northern groundwater pipeline system because of logistic restrictions associated with crossing the railroad right-ofway.)

\subsection{Regulatory Status of the Utica Program}

The CCC/USDA's primary objective for the activities at Utica is the treatment of carbon tetrachloride contamination in the shallow aquifer. The combined aquifer and wetlands restoration effort is being performed voluntarily by the CCC/USDA in cooperation with the wetlands agencies listed in Table 1.1. Throughout the conception, planning, design, and implementation of this program, the CCC/USDA has maintained communication with both the NDEQ and the U.S. Environmental Protection Agency Region VII (EPA) to keep these agencies fully apprised of activities at Utica and the North Lake Basin.

TABLE 1.1 Agencies participating with the CCC/USDA in the Utica-North Lake Basin pilot program. ${ }^{a}$

U.S. Environmental Protection Agency Region VII

U.S. Department of Agriculture, Natural Resources Conservation Service

U.S. Fish and Wildlife Service

Nebraska Department of Environmental Quality

Nebraska Game and Parks Commission

Upper Big Blue Natural Resource District

Rainwater Basin J oint Venture

City of Utica, Nebraska

a The CCC/USDA program at Utica is being conducted by the Environmental Research Division of Argonne National Laboratory. 
The only regulatory instrument presently affecting the operations at Utica is an NPDES permit requested from the NDEQ, governing the discharge of treated groundwater to Nebraska waters. The permit application identifies three separate outfalls from the groundwater treatment operations at the site, representing discharges from (1) the north spray irrigation unit, (2) the south spray irrigation unit, and (3) the air stripper at GWEX4.

The groundwater sampling and monitoring activities outlined here were developed to provide technically defensible data demonstrating the effectiveness of the installed extraction and treatment systems for remediation of the carbon tetrachloride plume. The monitoring program is designed to provide data of the type and quantity that are generally consistent with remedial actions regulated by the NDEQ or the EPA (under the Comprehensive Environmental Response, Compensation, and Liability Act). The monitoring program is based on the CCC/USDA's experience at the Waverly, Nebraska, remediation site. 


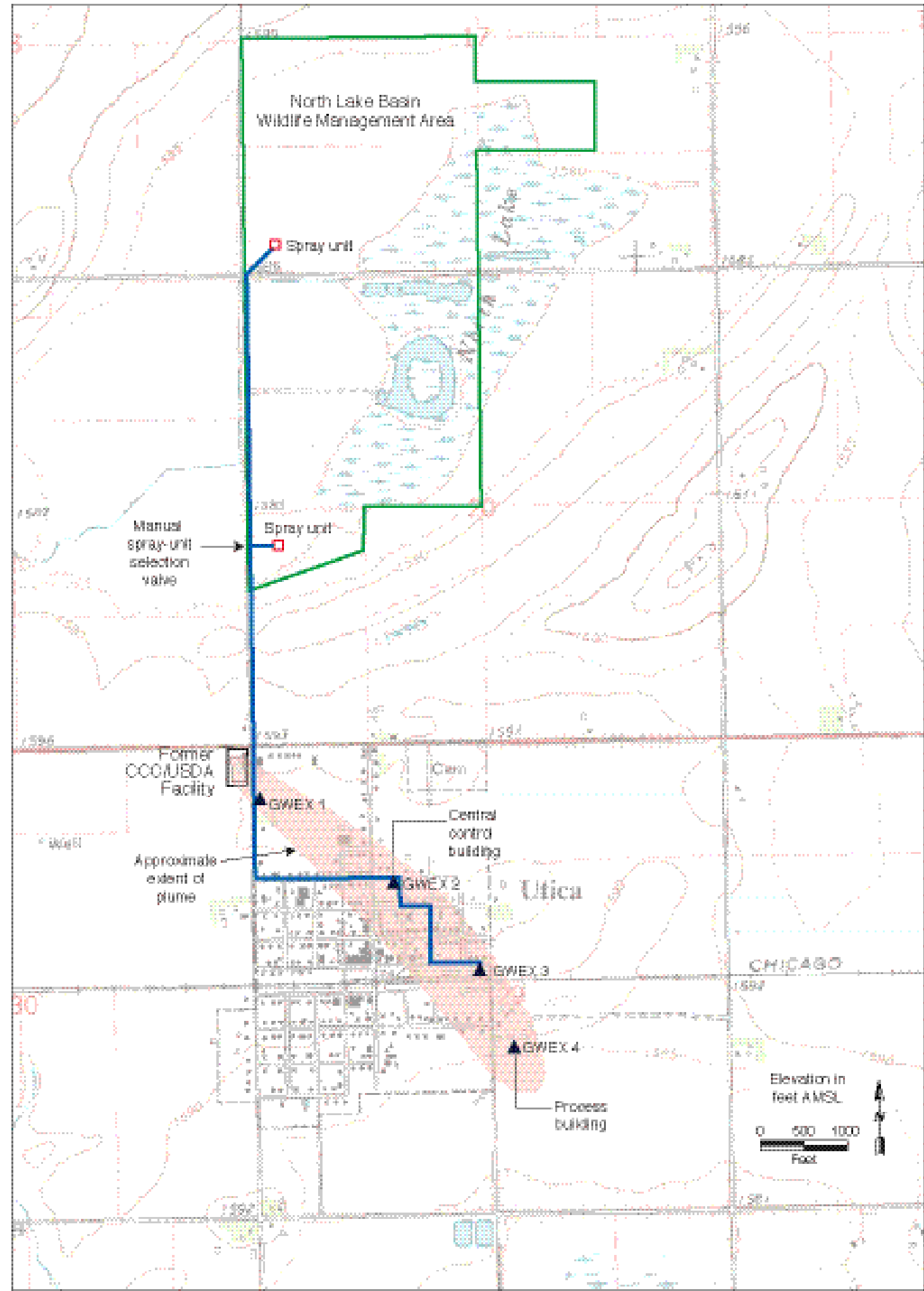

FIGURE 1.1 Locations of the primary groundwater extraction and treatment facilities at Utica, Nebraska. 


\section{Sampling and Monitoring Points}

This section describes the locations of points that are currently available for the sampling of groundwater and for the measurement of water levels, then presents recommendations for the installation of several additional permanent monitoring wells.

\subsection{Sampling Points for the Groundwater Extraction Wells and the Treatment Systems}

Groundwater produced from extraction wells GWEX1, GWEX2, and GWEX3 will be piped via individual lines to the central control building adjacent to GWEX2. There these streams will merge into one line for transfer to the North Lake Basin (Figure 1.1). A suitable manifold for this purpose, located in the central control building, is equipped with individual taps to permit sampling of the effluent from each extraction well, as well as the combined effluent from all three wells. Individual meters are installed on the incoming pipelines to record the total production and flow rates from each well.

The combined flow from GWEX1, GWEX2, and GWEX3 will be treated and discharged by using the spray irrigation unit (consisting of three irrigation spans) in either the north or south subbasin of the wetland; only one spray irrigation unit can be operated at any given time. Treated effluent from the spray irrigation unit should be collected for sampling by using (1) three standard rain gauges, located 30 in. above ground level, one beneath the midpoint of each spray irrigation span and (2) a fourth rain gauge to be similarly located at the site of the heaviest spray outfall at the time of sampling. The point of heaviest spray outfall is not fixed but depends on wind conditions and the spray head package (coarse or fine) in operation during sampling. The site of this fourth collection point will therefore vary from sampling event to sampling event and will have to be determined visually at the time of sample collection. This recommended sampling procedure is consistent with the protocols employed and the results obtained during previous investigation of the spray irrigation treatment process by Argonne under the Utica pilot testing program.

Untreated groundwater from well GWEX4 will be routed via a short pipeline to an adjacent process building that houses the air stripper. Taps have been installed in the process building to permit sampling of the influent groundwater from the well and the treated effluent 
from the air stripper. A totalizing flow meter is also located in the process building to determine the production and flow rate from GWEX4.

\subsection{Existing Sampling and Monitoring Points for the Groundwater Plume}

Figure 2.1 shows the locations of all of the monitoring wells, steel drive-point piezometers, and cone penetrometer piezometers that are presently accessible at Utica, in relation to the outline of the plume as it was mapped in February 2003 and the locations of the four GWEX wells. Construction information for these borings is in Table 2.1.

TABLE 2.1 Construction information for existing potential sampling and monitoring points at Utica.

\begin{tabular}{|c|c|c|c|c|}
\hline \multirow[b]{2}{*}{ Location } & \multicolumn{2}{|c|}{ Depth (ft BGL) } & \multirow[b]{2}{*}{ Type of Wella } & \multirow[b]{2}{*}{ Comment } \\
\hline & Total & Screen Interval & & \\
\hline SB48 & 98.5 & $83.5-93.5$ & 2-in. MW & $\begin{array}{l}\text { Does not penetrate the deeper, more } \\
\text { concentrated part of the carbon tetrachloride } \\
\text { plume. }\end{array}$ \\
\hline SB70 & 98.2 & $88-98$ & 2-in. MW & $\begin{array}{l}\text { Off migration pathway. Use limited to water } \\
\text { level monitoring. }\end{array}$ \\
\hline SB71 & 94.2 & 84- 94 & 2-in. MW & $\begin{array}{l}\text { Does not penetrate the deeper, more } \\
\text { concentrated part of the carbon tetrachloride } \\
\text { plume. }\end{array}$ \\
\hline SB72 & 122.3 & $82.6-112.6$ & 4-in. MW & $\begin{array}{l}\text { Penetrates the deeper, more concentrated } \\
\text { part of the carbon tetrachloride plume. }\end{array}$ \\
\hline FS13 & 95 & $89-95$ & CPT piezometer & $\begin{array}{l}\text { Does not penetrate the deeper, more } \\
\text { concentrated part of the carbon tetrachloride } \\
\text { plume. }\end{array}$ \\
\hline PS21 & 127.5 & $117.5-127.5$ & CPT piezometer & $\begin{array}{l}\text { Penetrates the deeper, more concentrated } \\
\text { part of the carbon tetrachloride plume. }\end{array}$ \\
\hline PS22 & 127.5 & $117.5-127.5$ & CPT piezometer & $\begin{array}{l}\text { Penetrates the deeper, more concentrated } \\
\text { part of the carbon tetrachloride plume. }\end{array}$ \\
\hline$P 1$ & 90.4 & 3-ft screen & SDP piezometer ${ }^{b}$ & $\begin{array}{l}\text { Does not penetrate the deeper, more } \\
\text { concentrated part of the carbon tetrachloride } \\
\text { plume. }\end{array}$ \\
\hline $\mathrm{P} 2$ & 89.1 & $86.1-89.1$ & SDP piezometer ${ }^{b}$ & $\begin{array}{l}\text { Off migration pathway. Use limited to water } \\
\text { level monitoring. }\end{array}$ \\
\hline
\end{tabular}

a Abbreviations: MW, monitoring well; CPT, cone penetrometer; SDP, steel drive-point.

b These steel drive-point piezometers were installed with the CPT in 1993 by pushing 1.25-in.-ID threaded steel pipe, plus a screen, into a pilot hole made with CPT rods. 
All of these borings are physically available for the measurement of water levels and groundwater sampling. Well SB70 and piezometer P2 lie off the identified plume migration pathway and hence are useful for water level measurements but not for monitoring of contaminant concentrations. Of the remaining borings, only SB72, PS21, and PS22 penetrate the deeper, more concentrated portions of the plume.

Current CCC/USDA and Argonne discussions with the Nebraska Department of Health and Human Services indicate that none of these borings may be acceptable to the state for groundwater sampling (or other uses). Abandonment of many or all of the installations might ultimately be required, and appropriate alternative monitoring points will then be needed.

\subsection{Recommendations for Additional Permanent Monitoring Wells}

In light of the findings about existing potential monitoring points discussed in Section 2.2, Argonne recommends installation of four new, conventionally drilled monitoring wells at locations MW1-MW4 (Figure 2.2) to serve as a minimal set of permanent groundwater sampling points in conjunction with the GWEX wells. The proposed well locations were chosen primarily for effective monitoring of several concentration "hot spots" identified in the contaminant plume. A secondary consideration is that these locations would provide a reasonable distribution of sampling points relative to the pumping wells, at sites believed to be accessible for the installations.

A fifth potential monitoring well (MW5; Figure 2.2) is suggested beyond the present toe of the plume to the southeast of GWEX4. The purpose of well MW5 would be to verify that the GWEX4 well is preventing continued downgradient extension of the plume. The logistic feasibility of well MW5 is uncertain, however, because a location in the middle of an annually cultivated field would be required. 


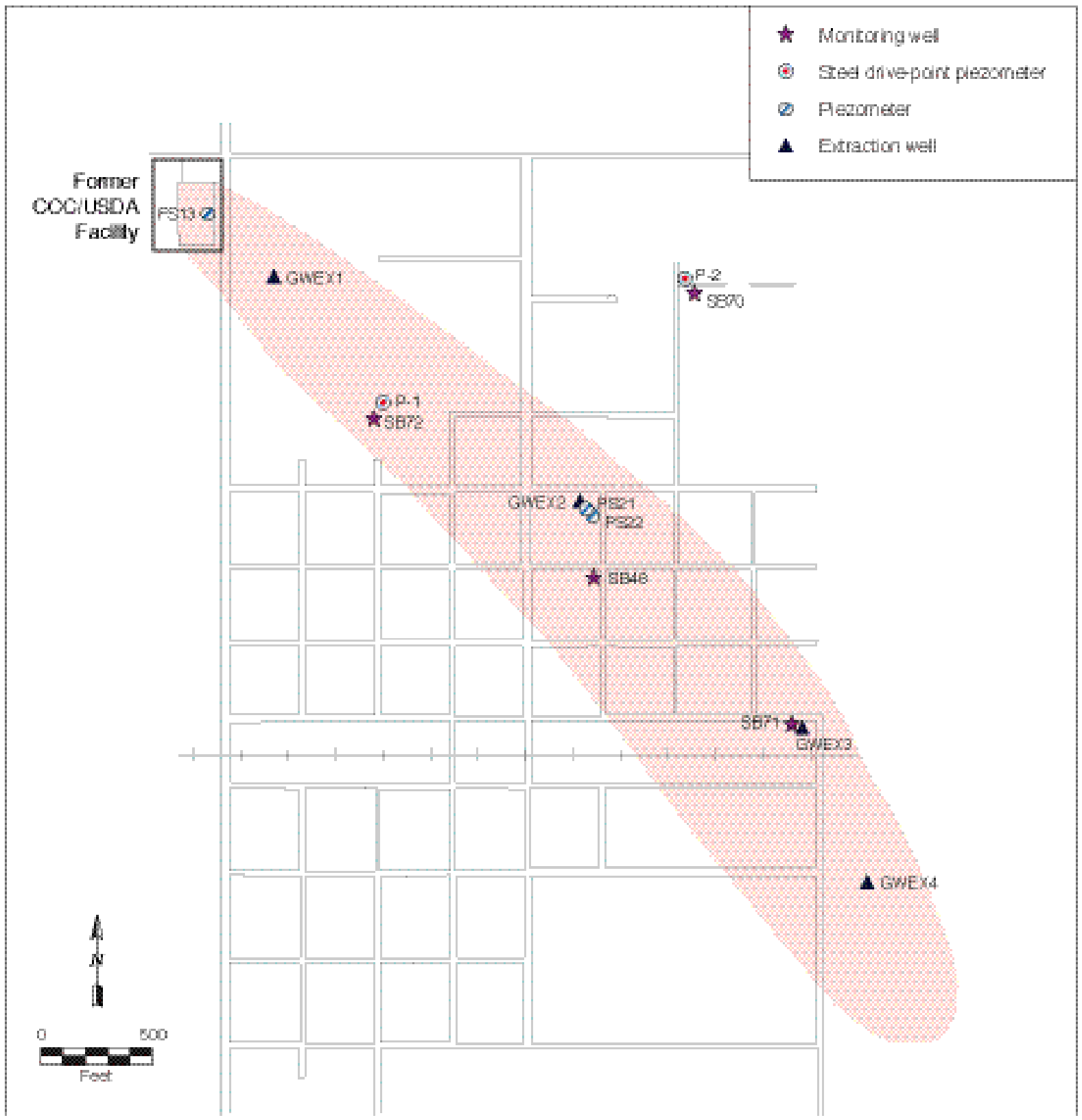

FIGURE 2.1 Locations of wells, steel drive-point piezometers, and cone penetrometer piezometers available for groundwater level monitoring and sampling as of J une 10,2004, relative to the carbon tetrachloride plume as mapped in February 2003. 


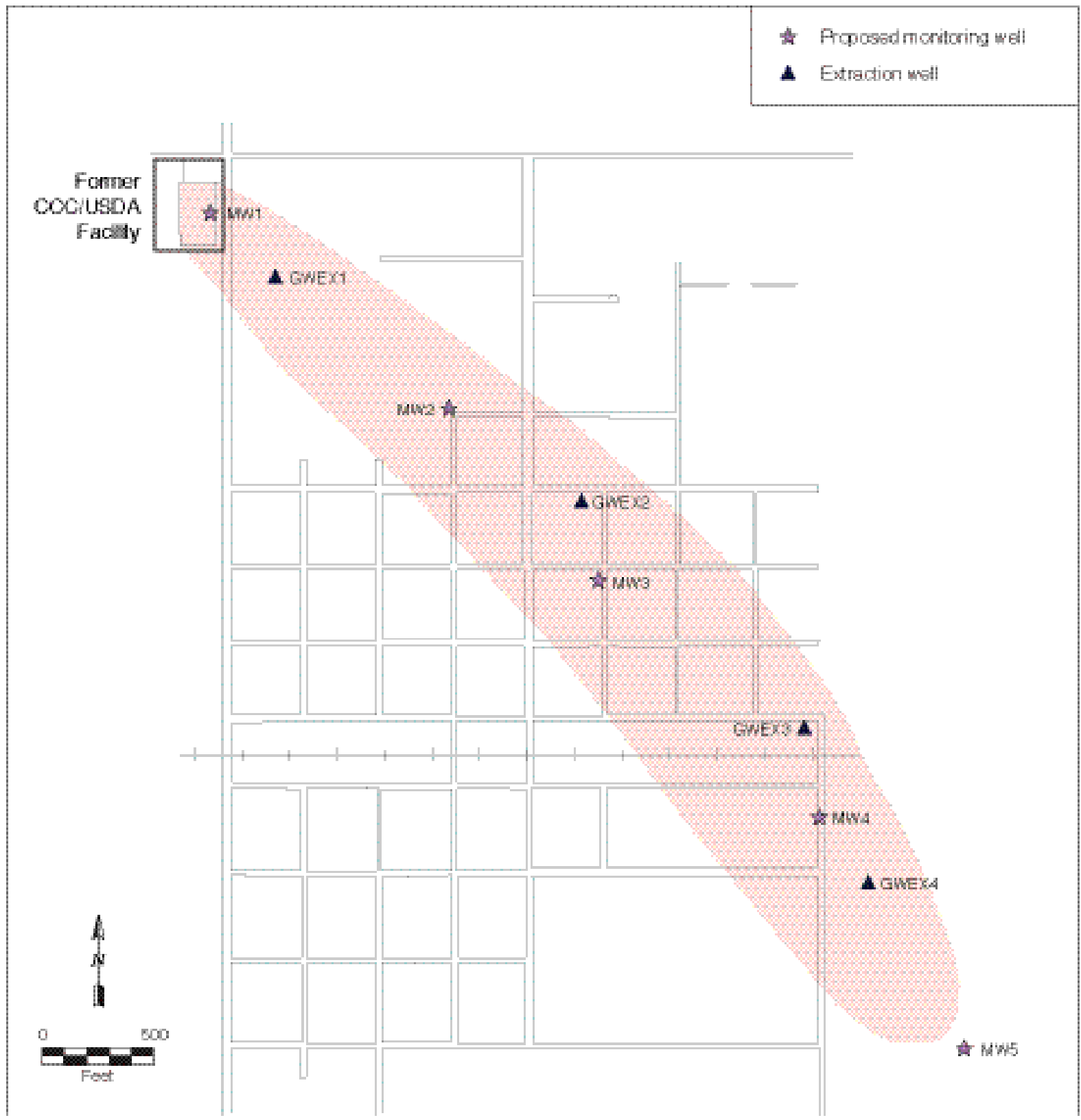

FIGURE 2.2 Suggested locations for new monitoring wells, relative to the groundwater extraction wells and the carbon tetrachloride plume as mapped in February 2003. 


\section{Monitoring Programs}

This section outlines two phases of groundwater sampling and systems monitoring recommended for the Utica site. The phases are (1) the initial testing and start-up of the GWEX wells and treatment facilities and (2) subsequent routine monitoring to be conducted for the duration of the restoration effort.

\subsection{Initial (Confirmation) Sampling and Monitoring}

A period of relatively intense groundwater sampling during the first few weeks of operation of the GWEX wells and treatment systems at Utica will establish the starting concentrations at each designated sampling point and confirm the effectiveness of the treatment systems. Table 3.1 summarizes the recommendations.

The initial groundwater sampling event will immediately follow the first continuous 24-hr period of operation (to facilitate purging) of all four GWEX wells and the associated treatment systems. Samples will be collected for VOCs analyses from the treatment system and monitoring well locations shown in Table 3.1. Additional groundwater samples from the treatment system locations will be analyzed for cations and anions to provide baseline inorganic geochemical data on the composition of the local groundwater and the water being discharged to the surface both in the wetlands and southeast of the town. In addition, groundwater levels will be measured at all available monitoring points, and the flow rates from each GWEX well will be recorded.

Weekly monitoring for a subsequent period of one month is recommended to confirm the initial sampling results and identify short-term trends that might appear in the operating wells and treatment systems or in the groundwater contaminant concentrations. Groundwater sampling is recommended for only VOCs analyses during four consecutive sampling events at the GWEX wells and treatment systems. Flow rates from the GWEX wells will also be determined each week. Water levels will be measured weekly at the available monitoring points and recorded continuously with automatic data loggers at selected monitoring wells (to be determined). The purpose will be to evaluate the stability of GWEX operations and their effects on groundwater levels in the contaminated aquifer, as well as to verify the effective operation of the treatment systems. 
TABLE 3.1 Monitoring plan for the Utica spray irrigation treatment system.

\begin{tabular}{|c|c|c|c|c|c|c|c|c|c|c|c|}
\hline \multirow[b]{2}{*}{$\begin{array}{c}\text { Monitored Location } \\
\text { or Quantity }\end{array}$} & \multicolumn{4}{|c|}{ Initial Start-up Samplinga } & \multicolumn{3}{|c|}{$\begin{array}{l}\text { Weekly Sampling for } \\
\text { One Month after } \\
\text { Start-up or Restart }\end{array}$} & \multicolumn{3}{|c|}{$\begin{array}{l}\text { Long-Term } \\
\text { Monthly Sampling }\end{array}$} & \multirow{2}{*}{$\begin{array}{l}\text { Long-Term } \\
\text { Annual } \\
\text { Sampling for } \\
\text { Inorganics }^{\text {b }}\end{array}$} \\
\hline & VOCs & Inorganicsb & $\begin{array}{l}\text { Water } \\
\text { Levels }^{c}\end{array}$ & $\begin{array}{l}\text { Flow } \\
\text { Rates }\end{array}$ & VOCs & $\begin{array}{l}\text { Flow } \\
\text { Rates }\end{array}$ & $\begin{array}{l}\text { Water } \\
\text { Levels }^{c}\end{array}$ & VOCs & Production & $\begin{array}{c}\text { Water } \\
\text { Levels }^{c}\end{array}$ & \\
\hline \multicolumn{12}{|l|}{ Treatment System } \\
\hline GWEX1 (untreated flow) & $x$ & $x$ & & $x$ & $x$ & $x$ & & $x^{d}$ & & & $x$ \\
\hline GWEX2 (untreated flow) & $x$ & $x$ & & $x$ & $x$ & $x$ & & $x^{d}$ & & & $x$ \\
\hline GWEX3 (untreated flow) & $x$ & $x$ & & $x$ & $x$ & $x$ & & $x^{d}$ & & & $x$ \\
\hline $\begin{array}{l}\text { Combined GWEX1 + } \\
\text { GWEX2 + GWEX3 } \\
\text { (untreated flow) }\end{array}$ & $x$ & $x$ & & & $x$ & & & $x^{d}$ & & & $x$ \\
\hline $\begin{array}{l}\text { Treated discharge from } \\
\text { operating spray irrigation } \\
\text { unit }\end{array}$ & $x$ & $x$ & & & $x^{e}$ & & & $x^{f}$ & & & $x$ \\
\hline GWEX 4 (untreated flow) & $x$ & $x$ & & $x$ & $x$ & $x$ & & $x^{d}$ & & & $x$ \\
\hline $\begin{array}{l}\text { Treated effluent from } \\
\text { GWEX4 air stripper }\end{array}$ & $x$ & $x$ & & & $x$ & & & $x$ & & & $x$ \\
\hline
\end{tabular}

\begin{tabular}{|c|c|c|c|c|c|}
\hline \multicolumn{6}{|c|}{ Monitoring Wells } \\
\hline SB48g & $x$ & $x$ & $x$ & $x$ & $x$ \\
\hline SB 719 & $x$ & $x$ & $x$ & $x$ & $x$ \\
\hline SB72g & $x$ & $x$ & $x$ & $x$ & $x$ \\
\hline$M W 1^{h}$ & $x$ & $x$ & $x$ & $x$ & $x$ \\
\hline$M W 2^{h}$ & $x$ & $x$ & $x$ & $x$ & $x$ \\
\hline$M W 3^{h}$ & $x$ & $x$ & $x$ & $x$ & $x$ \\
\hline$M W 4^{h}$ & $x$ & $x$ & $x$ & $x$ & $x$ \\
\hline$M W 5^{h}$ & $x$ & $x$ & $x$ & $x$ & $x$ \\
\hline
\end{tabular}

Metered and Calculated Quantities for NPDES Requirements

Total Volume Produced per

GWEX

Number of Days of

Operation per GWEX

Average Flow Rate per

GWEX

Quantity of Treated Water

from North S pray

Irrigation Unit

Quantity of Treated Water

from South Spray

Irrigation Unit

Quantity of Treated Water

from GWEX 4 Air Stripper

a Sampling is to occur immediately after the first $24 \mathrm{hr}$ of operation.

b Analyses will be for cations and anions.

c Measurements are to be recorded with automatic data loggers.

d Sampling of GWEX1, GWEX2, GWEX3, and their combined flow is to occur at least once during any calendar month when these wells are operating. GWEX4 is to be sampled every month.

e During the initial month of operation of the treatment system, each spray irrigation unit should be operated at least twice for periods of at least $24 \mathrm{hr}$, long enough to permit sampling of the spray discharge at each unit. Aside from this need, the NGPC will determine which unit will be operated.

f Each spray irrigation unit should be operated at least twice each year for periods of at least $24 \mathrm{hr}$, long enough to permit "monthly" sampling of the spray discharge at each unit for VOCs during at least two months. Aside from this need, the NGPC will determine which unit will be operated.

g If available (Section 2.2). Locations are in Figure 2.1

$\mathrm{h}$ If installed (Section 2.3). Locations are in Figure 2.2. 
Per previous discussions between the CCC/USDA and the Nebraska Game and Parks Commission (NGPC), the NGPC will determine which of the North Lake subbasins receives groundwater at any given time, as well as the schedule for groundwater pumping (subject to total annual production requirements to be negotiated with the CCC/USDA and Argonne). During the initial month of operation of the GWEX wells, however, each spray irrigation unit should be operated at least twice for at least $24 \mathrm{hr}$ per event, periods sufficient to permit sampling of the spray discharge at each of the units.

If difficulties are encountered during the initial month of operation of the GWEX wells or the treatment systems, or if conditions at any subsequent time require significant changes in the critical operating parameters for these systems, the weekly sampling and monitoring activities outlined above should be instituted (or continued) until a stable operating configuration is demonstrated for one month (four consecutive sampling events).

The results of the initial sampling and monitoring activities will be documented in a separate report.

\subsection{Long-Term Sampling and Monitoring}

Monthly sampling will begin after stable operating conditions have been demonstrated in four consecutive weekly monitoring events, as outlined in Section 3.1. Monthly sampling activities are summarized in Table 3.1. The recommended monthly sampling and monitoring program will document the continuing performance of the GWEX wells and treatment systems at Utica and will provide data needed to comply with the anticipated requirements of the NPDES permit for this site. Metered and calculated quantities needed for this latter purpose are the total volume of groundwater produced, the number of days of operation, and the average flow rate for each GWEX well, as well as the quantity of treated groundwater discharged from each of the three NPDES-permitted outfalls (the two spray irrigation units and the GWEX4 air stripper).

Because GWEX1, GWEX 2, GWEX3, and the spray irrigation treatment units are expected to operate seasonally and might follow a different schedule from one year to the next, flexibility is required in "monthly" sampling of these systems for VOCs analyses. Such sampling is recommended at least once during any calendar month when the respective extraction well or spray unit is in operation. 
The frequency with which the NGPC will divert groundwater to either the north or south spray irrigation unit is also presently unknown and could change on an irregular basis. Each spray irrigation unit, however, should be operated at least twice each year for at least $24 \mathrm{hr}$ per event, periods sufficient for "monthly" sampling of the spray discharge at each unit for VOCs analyses during at least two months.

Groundwater sampling for inorganic geochemical analyses is recommended once annually at the treatment system locations to document the composition of the local groundwater and the water being discharged to the wetlands and to the surface southeast of Utica.

The results of these monitoring activities will be reported quarterly in a format similar to that currently used by the CCC/USDA and Argonne for the groundwater remediation activities at Waverly, Nebraska.

The presently estimated time frame for restoration of the Utica aquifer with the facilities and seasonal pumping scenario outlined above is approximately 15 years. To obtain a detailed picture of the progress of the restoration effort toward completion, groundwater sampling with the cone penetrometer, as performed at the site by Argonne in 1998 and again in 2003 (for example, Figure 1 in Argonne 2003), is recommended at 5-year intervals after the start-up of the treatment facilities.

\subsection{Procedures for Sampling and Analyses}

Groundwater sampling from existing wells or with the cone penetrometer and analyses of the samples will be conducted in accordance with procedures in the Master Work Plan (Argonne 2002) for investigations in Nebraska. Upon collection, the samples collected for VOCs analyses will be preserved on ice in the field and shipped to the Applied Geosciences and Environmental Management Laboratory at Argonne for analysis. Samples collected for cation and anion determinations will be analyzed at a certified reference laboratory.

Argonne will establish detailed procedures for sampling the treated discharge from the operating spray irrigation units. These procedures will be described in a separate document. 


\section{References}

Argonne, 2002, Final Master Work Plan: Environmental Investigations at Former CCC/USDA Facilities in Nebraska, 2002 Revision, ANL/ER/TR-02/003, prepared for the Commodity Credit Corporation, U.S. Department of Agriculture, by Argonne National Laboratory, Argonne, Illinois, December.

Argonne, 2003, Update on Groundwater Sampling Results for Utica, Nebraska, and Pumping Alternatives for the Utica Aquifer/Wetlands Restoration Pilot Program, ANL/ER/AGEM/CHRON-484, prepared for the Commodity Credit Corporation, U.S. Department of Agriculture, by Argonne National Laboratory, Argonne, Illinois, April 9. 